Миланка П. Бабић Вукадинов

milabv@gmail.com

Биљана Т. Петровић

petrovic.bp@gmail.com

Библиотека града Београда
Стручни рад

UDK 027.5(497.11)"2020"

028.8(497.11)"2020"

https://doi.org/10.18485/bibliotekar.2020.62.2.10

\title{
РАД БИБЛИОТЕКА(РА) ТОКОМ ПАНДЕМИЈЕ НА ПРИМЕРУ ДЕЧЈЕГ ОДЕЉЕЊА БИБЛИОТЕКЕ ГРАДА БЕОГРАДА
}

Сажетак: Тема рада су новонастали начини спровођења програмских делатности током пандемије корона вируса у периоду када је Библиотека града Београда привремено била затворена за кориснике. Представљени су задати правни оквир и начини прилагођавања рада у условима који подразумевају социјалну дистанцу и затварање библиотека за кориснике услед ширења вируса и проглашења ванредног стања. На примеру Дечјег одељења БГБ приказане су могућности које су се отвориле за рад у виртуелном окружењу. Истакнута је важност одржавања контаката са корисницима и сарадницима и умрежавање са другим радницима у области културе.

Изазовна ситуација подстакла је нове облике рада библиотекара и прилику да се неки од програмских садржаја из реалног простора пребаце у виртуелни како би се читалачка публика анимирала. Наглашена је важност интеракције са најмлађим читаоцима, као и пружање препорука за читање и релевантних информација како се не би дозволио прекид континуитета у раду.

Кључне речи: Библиотека града Београда, ванредно стање - библиотеке, правни оквир рада БГБ, Дечје одељење, програмске активности.

\section{Увод}

У марту 2020. Србија се суочила са голим оком невидљивим непријатељем који је напао целу планету. На телевизији су се приказивале апокалиптичне слике из Кине, а потом из Италије, да би убрзо сличне слике стизале из Шпаније, Велике Британије, Русије, САД, Индије, Аргентине и 
других земаља. Пандемија корона вируса учинила је да свакодневица буде тешка на свим меридијанима, у свим делатностима, а изузетак нису биле ни библиотеке.

Процес престанка непосредног рада са корисницима због епидемије ковида-19 у Србији, али и пандемије у свету, који је погодио и велики број библиотека, нешто је што се никада није догодило у историји јавног библиотекарства. Самим тим нико није имао искуства, и сви су се руководили упутствима кризних штабова и саветима епидемиолога.

Библиотека града Београда спада у библиотечке системе главних градова; њен слоган је Куличурно срие Беоїраgа јер љубитељима уметности и лепе речи омогућава да уживају у преко 3.000 културних програма током целе године. У БГБ мрежи, на седамдесетак локација, ради више од 230 запослених, има фонд од скоро два милиона књига, око 150.000 чланова и два милиона посета годишње. Међутим, у марту је због ширења епидемије корона вируса одједном све стало. Ипак, помоћу интернета и друштвених мрежа запослени у Библиотеци успели су да се изборе са новим изазовима и прилагоде и своје програме и друге процесе рада новонасталој ситуацији. Током ванредног стања Библиотека је била затворена за кориснике, а запослени су своје радне задатке обављали од куће. У процесу рада од куће библиотекари су радили и много „невидљивог посла” у вези са каталозима, базама, имали су онлајн припреме за коришћење нових програма.

Библиотека је прешла на виртуелни начин комуникације са својим члановима и јавношћу, користећи дигиталне медије, друштвене мреже, онлајн платформе, настојећи да контакт буде сталан и да „остајући код куће” корисници могу ипак о свему да добију обавештење на сајту www.bgb.rs.

\section{Правни оквир рада Библиотеке града Београда у ванредном стању}

Законска акта која регулишу понашање и рад грађана у Београду и рад БГБ донео је Секретаријат за културу Скупштине града Београда, на основу Одлуке о увођењу ванредног стања. ${ }^{1}$ Организација рада градских установа имала је три фазе.

У првој фази, од 16. до 22. марта 2020. године, установа „функционише са минимумом рада" који одређује директор, процењујући који је то

Ванредно стање уведено је 16. марта 2020. 
минимум „без угрожавања здравља запослених, а у складу са ванредним стањем” и са молбом за строго придржавање прописаних мера. Процес рада и даље се одвијао у радном простору, с тим што су неке категорије запослених могле да раде и од куће. ${ }^{2}$

У другој фази, од 24. марта до 3. маја 2020. године, услед погоршања епидемиолошке ситуације, у складу са новим мерама за заштиту од ширења заразне болести ковид-19 којима је кретање минимализовано, прекинут је процес рада у простору библиотека. Сви запослени радили су од куће, и на основу Уредбе о организовању рада послодаваца за време ванредног стања добијали су Решење о обављању послова ван просторија послодавца (рад на даљину и рад од куће), по коме су морали да обављају послове књижничара/библиотекара са пуним радним временом, у трајању од осам часова дневно и 40 часова недељно, у времену од 8 до 16 часова; надзор над радом запосленог и вођење евиденције о њему за време рада ван просторија послодавца обављао је непосредни руководилац, док је запослени био дужан да једном седмично, електронским путем, непосредном руководиоцу доставља извештаје о раду. ${ }^{3}$ Управо ће могућности рада током ове фазе бити детаљније представљене касније у тексту.

Трећа фаза рада почела је 3. маја 2020. године повратком запослених у радни простор. ${ }^{4}$ Ванредно стање је укинуто, ${ }^{5}$ али одређене мере заштите су остале. ${ }^{6}$

2 На основу одлуке Секретаријата за културу Градске управе града Београда VI-2, бр.03199/20-Н.М. од 16. 3. 2020. категорије запослених које могу да раде од куће су: старији од 60 година, сви тешки хронични болесници (дијабетичари, лица са дијагностикованим канцером, лица са болестима срца и плућа), труднице и самохране мајке и родитељи са децом; као и лица која су имала проблем у доласку на посао (већа удаљеност, коришћење више линија градског превоза, редуковање броја возила и сл.).

3 Радне обавезе запослених проистекле су из низа законских аката: Закона о раду, Посебног колективног уговора и Уговора о уређивању међусобних права, обавеза и одговорности / Уговора о раду са запосленим.

4 Министарство културе и информисања упутило је препоруку свим библиотекама, архивима, музејима и галеријама у Србији да од 22. априла 2020. године наставе рад, уз стриктно поштовање свих превентивних мера заштите.

5 Народна скупштина Републике Србије донела је Одлуку о укидању ванредног стања, које је укинуто 7. маја 2020. Одлука о проглашењу заразне болести COVID-19 и Наредба о проглашењу епидемије и даље су биле на снази, тако да укидањем ванредног стања није престала примена епидемиолошких мера.

6 Влада Републике Србије донела је 7. маја 2020. године Инструкције о организацији радних процеса у органима државне управе и служби Владе у примени превентивних мера које се односе на спречавање ширења заразне болести COVID-19 након укидања ванредног стања. 
Библиотека није одмах увела рад са корисницима, по препоруци Кризног штаба Града Београда и Секретаријата за културу, већ је постепено отварање објеката почело од 11. маја 2020. године (прво само централних општинских библиотека, а касније и огранака), према прилагођеном распореду и радном времену, и уз поштовање мера заштите које је прописао Градски завод за јавно здравље.

\section{Културни програми Библиотеке града Београда}

Библиотекари су, у периоду када је кретање било ограничено, брзо и примерено реаговали тако што су корисницима понудили низ садржаја на интернету, што је данас незаобилазна активност сваке установе. Одељење за културне програме Библиотеке града Београда било је врло активно на друштвеним мрежама, трудећи се да програмску шему прилагоди новонасталој ситуацији. Од почетка ванредног стања реализован је низ програма на Фејсбук страници и Јутјуб каналу, тако да је Библиотека непрекидно присутна у јавности, што је и био циљ. Једна од акција, названа „Читам, не скитам!” одржана је у периоду од 18. до 30. марта са циљем да подстакне читање. Корисници су позвани да поделе цитате из омиљених књига на Фејсбук страници Библиотеке града, а десет најлепших цитата било је награђено.

Одмах затим покренут је и онлајн фото-конкурс „Читам, не скитам! Са књигом се сликам!", намењен старијима од 18 година који су на Фејсбук страницу Библиотеке града постављали фотографије најдражих књига у изабраном амбијенту. ${ }^{7}$ На тај је начин обележен и 23. април - Светски дан књиге. Овај конкурс са циљем да се промовишу читање и култура подржале су многе личности из јавног живота. ${ }^{8}$

Организовано је и виртуелно читалиште Града Београда „Прочитај ми моју жељу” у коме су учесници на званичној Фејсбук страни БГБ писали чију би поезију желели да чују и виде у извођењу глумаца. Глумци су читали по два читалачка предлога која су добила највише лајкова на сваких седам дана.

Сваки учесник могао је да постави по једну фотографију на зид ФБ стране БГБ, у коментарима испод поста којим је отворен конкурс. Аутори десет фотографија који су имали највећи број лајкова, били су награђени годишњом чланарином и књигом.

8 Јавне личности су подржале ову акцију препоручивши своје омиљене књиге, чиме су као промотори акције мотивисали читаоце да пошаљу фотографију омиљене књиге у кућном окружењу. 
Библиотека града понудила је такође и изузетан избор документарних и краткометражних филмова преко свог онлајн сервиса, а љубитељима књиге на располагању је била и дигитална библиотека, која поседује богат садржај старе и ретке библиотечке грађе: од књига, преко новина, географских карата итд. На порталу Библиотеке могле су такође да се погледају и електронске изложбе.

\section{Програми Дечјег одељења Библиотеке града Београда}

Током увођења ванредног стања и обуставе рада са корисницима у простору Библиотеке и Дечје одељење Библиотеке града Београда „Чика Јова Змај” настојало је да се прилагоди новој ситуацији. Библиотекари су пред собом имали изазов како да изађу у сусрет потребама читалаца и сачувају контакт са корисницима и сарадницима. Требало је прећи на онлајн рад од куће и размислити на које све начине могу да се анимирају деца и родитељи. Било је потребно смислити интерактивне активности и пружити читаоцима одређене услуге.

Једно од првих питања које су библиотекари себи поставили било je: да ли је могуће неке од програма који се редовно одржавају у дечјој библиотеци пренети у виртуелни простор? Тако се дошло до закључка да вреди покушати да се деца и родитељи подстакну на креативни рад, и то позивањем на учешће у активностима које су уобичајено приређиване у библиотеци, као што су:

1) „Оживљавање” прича

У Дечјем одељењу редовно се одржавају програми приповедања прича, за које реквизите (ликове, предмете) праве библиотекари, а понекад то чине и сама деца или деца и родитељи, заједничким снагама. Када се реквизити фотографишу и сними глас једног детета или гласови више деце која наизменично читају причу, фотографије и глас(ови) убацују се у програм за прављење филмића. На такав начин приче су у библиотеци оживљаване на редовним радионицама у којима учествују деца и родитељи, вртићке групе или цели разреди. Идеја је била да се током пандемије родитељи подстакну и упуте у то како са децом могу да креирају реквизите и направе сопствени филмић, који би затим јавно поделили на Фејсбук страници Дечјег одељења. Зато су на страници постављени примери таквих обрада: народна песма „Ја сам чудо видео” и басна „Чавка и друге птице”, коју су на радионицама, уз помоћ библиотекара, извели родитељи и деца. Преко Фејсбука дат је и текст афричке басне о колибрију као предлог за 
стваралачки рад: прављење ликова из басне, тј. реквизита, а потом и филмића. Иако је предлог био захтеван, једна породица снимила је и поделила са библиотекарима Дечјег одељења и читалачком публиком на Фејсбуку своју луткарску представу „Прича о доброј роди”.

Поред тога, анимирани филм ауторке Еве Цвијановић „Јежурка Јежић”, постављен на Фејсбук страни Дечје библиотеке „Чика Јова Змај”, био је позив деци за налажење сопствених креативних решења да представе ово познато и многима омиљено дело Бранка Ћопића. Тако су пристигли њиме надахнути новинарско-уметнички запис „Вести из несвести” и видео-запис луткарске представе „Јежева кућица”, које је сачинило двоје првака ОШ „Никола Тесла”. Ћопићев јунак надахнуо је и децу из школе глуме „Мали Принц”, те је добијен и преко Фејсбука са читаоцима подељен и видео-снимак њиховог извођења овог Ћопићевог дела.

2) Позив на игру

У библиотеци радо извођена интерактивна радионица о идиомима такође се преселила на интернет. Уместо цртањем на табли, деца су анимирана да код куће ликовно представе идиоме српског језика и фотографисане цртеже поставе на Фејсбук страну Дечјег одељења, а библиотекари и други корисници, који имају налог на овој друштвеној мрежи, погађали су на основу цртежа о којем идиому је реч. Ова и забавна и едукативна радионица намењена је старијим основцима, али се међу учесницима у игри на интернету нашао и један предшколац којег су родитељи подстакли на цртање, укључивши се тако и сами у игру.

\section{3) „Страшан лав”}

На Фејсбук страни постављена је необична рок изведба познате песме Душка Радовића „Страшан лав”. Деца су позвана да ликовно представе Радовићевог лава и да на страници библиотеке поделе своје цртеже, што се испоставило као интересантан задатак за младе читаоце, те је стигло више маштовитих радова.

4) Креативно писање

Радионица креативног писања такође се из простора библиотеке преселили у виртуелни простор. Часови писања одржавани су преко апликације Zoom, а стигла је и вест да је учесница ове радионице за свој рад „Шта деца сањају” добила другу награду на литерарном конкурсу „Гордана Брајовић” Центра за културу и уметност Алексинац. 


\section{Одржавање веза са сарадницима}

Током пандемије било је веома важно одржавати везе са сарадницима. Библиотекарка Александра Дракулић из Основне школе „Никола Тесла”, једна од дугогодишњих сарадница, помагала је члановима литерарне секције коју води у својој школи да се повежу са Дечјим одељењем Библиотеке града. Посредовала је између ученика и библиотеке тако што је децу редовно информисала о активностима Дечјег одељења, а библиотеци слала дечје радове. На страници библиотеке су стога, на задовољство обеју страна, дељени стваралачки радови ученика ОШ „Никола Тесла”.

Библиотекари Дечјег одељења такође су се трудили да обавесте кориснике-децу и о активностима својих сарадника, нпр. о Јутјуб каналу Јасминке Петровић „Читањац, играњац”, о идејама за боравак у кући глумице Маје Зорое, која води Школу глуме „Мали Принц”, о конкурсу за децу „Лутка сјајна мог дизајна” учитељице Аните Пешић која дизајнира лутке. Подељена је „Апћиха прича”, коју чита Тања Лебовић, сарадница из Издавачке куће Propolis Books, која редовно одржава промоције књига за децу у огранцима Библиотеке града.

\section{Пружање препорука за читање}

Веома важно за библиотекаре Дечјег одељења је да буду упознати са новим насловима како би деци могли да препоруче уметнички вредно и забавно штиво. Током пандемије они су писали препоруке за књиге за децу и младе, које су у сарадњи са Одељењем за културне програме БГБ редовно постављане на портал „Шта да читамо”, на коме библиотекари јавних библиотека из Србије, књижевници и књижевни критичари дају препоруке за читање.

\section{Жирирање литерарно-ликовних конкурса}

Библиотека града већ пету годину за ученике основне школе организује литерарно-ликовни конкурс „Читам, па шта!”, а Дечје одељење Библиотеке града традиционално у јануару расписује литерарно-ликовни конкурс поводом Светског дана књиге за децу. Ове године задата тема била је инспирисана „Изокренутом причом” Бранка Ћопића и гласила је 
„Обрни, окрени причу/песму/слику изокрени”, а рок за слање радова је због пандемије продужен до почетка рада библиотеке.

Испоставило се да је велика предност то што ученички радови на конкурс „Читам, па шта!” стижу искључиво у електронском облику и постављају се на сајту https://citampasta.rs, тако да их свако, у било ком тренутку од момента постављања, може видети и прочитати, јер су тако и библиотекари Дечјег одељења могли лако да обаве жирирање радова радећи од куће. Такође је и највећи број радова на конкурс „Обрни окрени причу/песму/слику изокрени” стигао преко електронске поште, што се у насталој ситуацији показало као олакшавајућа околност.

\section{Информативност и обележавање значајних датума}

Библиотекари нису пропустили да на одређени начин на Фејсбук страни обележе Дан књиге за децу и Светски дан књиге, као и Ускрс, постављањем прилога које су сами бирали, али и које су слали родитељи деце, попут рецимо видео-снимка детета-корисника које рецитује ускршњу песму.

На крају, али не мање важно, треба рећи и то да су се библиотекари трудили да у виртуелном простору поделе корисне информације, а на самом почетку пандемије, као увод у све што се дешава, пружене су дечјем узрасту прилагођене информације о заштити од болести.

\section{Закључак}

Иако је пандемија дошла изненада, и иако је уобичајен рад отежан, она је подстакла библиотекаре да траже и проналазе нове начине комуникације и рада са читаоцима и да више користе могућности интернета и друштвених мрежа. Интернет је омогућио библиотекама да йреживе пандемију и ојачао је нови вид комуникације на релацији библиотека-корисник. Нешто што је раније било у зачетку, попут премештања и одржавања литерарно-ликовног конкурса искључиво слањем и добијањем радова путем имејла и њиховим постављањем на одређени сајт („Читам, па шта!”) испоставило се сада као добро решење. Недостатак културне анимације у стварном простору надомештен је виртуелним, који се показао као једино и добро решење за очување контаката са корисницима и сарадницима, а тиме на првом месту за одржање културе читања и позитивног односа према библиотеци. 


\section{Literatura:}

1. Dopis Gradske uprave grada Beograda - Sekretarijat za kulturu VI-02 br. 031-99/20. N.M.- 16. 3. 2020.

2. http://www.bibliotekagm.com/wp-content/uploads/2020/07/PLAN-PREVENTIVNIH-MERA- ZA-BEZBEDAN-I-ZDRAV-RAD-ZA- SPRE\%C4\%8CAVANJE-KORONE.pdf

3. Instrukcije o organizaciji radnih procesa u organima državne uprave i službi Vlade, https://www.paragraf.rs/propisi/pravilnik-o-preventivnim-merama-bezbedanzdrav-rad-sprecavanje-epidemije.html

4. Službeni glasnik RS, br. 31/2020.

5. Službeni glasnik RS, br. 63/2020.

6. Statut Biblioteke grada Beograda br. 4811 od 1. 11. 2017. godine.

7. Uredba o organizovanju rada poslodavaca za vreme vanrednog stanja. Službeni glasnik RS, br. 31/2020.

8. Uredba o organizovanju rada poslodavaca za vreme vanrednog stanja (https://www. paragraf.rs/propisi/odluka-o-odredjivanju-posebnih-mera-zaštite-stanovništvacovid-19-beograd.html)

9. Zakon o radu, Službeni glasnik RS br. 24/05, br. 61/05, br. 54/09, br. 32/13, br. 75/14, br. 13/2017- Odluka US 113/20176 i 95/2018. 


\title{
Milanka P. Babić Vukadinov
}

milabv@gmail.com

Biljana T. Petrović

petrovic.bp@gmail.com

Belgrade City Library

\section{THE WORK OF LIBRARIES (LIBRARIANS) DURING THE PANDEMIC ON THE EXAMPLE OF THE CHILDREN'S DEPARTMENT OF THE BELGRADE CITY LIBRARY}

\begin{abstract}
This paper deals with the newly created ways of program activities during the coronavirus pandemic in the period when the Belgrade City Library was temporarily closed. The given legal framework and ways of adjusting the work to the conditions that imply social distance and closing libraries for users due to the spread of the virus and the declaration of a state of emergency are presented. The example of the Children's Department shows the possibilities that have opened up for working in a virtual environment. The importance of maintaining contacts with users and associates and networking with other cultural workers is emphasized.

The challenging situation encouraged new forms of library activities and the opportunity to transfer some of the programs from the real to the virtual space to animate the reading audience. The importance of interacting with the youngest readers is emphasized, as well as the provision of reading recommendations and relevant information in order to prevent the discontinuation of work.
\end{abstract}

Keywords: Belgrade City Library, emergency state - libraries, legal framework of the Belgrade City Library, Children's Department, program activities.

Примљено: 9. септембра 2020.

Прихваћено: 19. октобра 2020. 